\title{
A geomorphological approach for enhancing environmental management and conservation of landforms as protected nature objects in the Upper Daugava spillway valley
}

\author{
Evita Muižniece ${ }^{1}$, Juris Soms ${ }^{2}$ \\ ${ }^{1}$ University of Latvia, Address: Raina Blvd. 19, Riga, LV 1586, Latvia; \\ ${ }^{2}$ Daugavpils University, Address: Vienības Street 13, Daugavpils, LV-5401, Latvia
}

\begin{abstract}
This paper describes the application of geomorphological approach for environmental management and conservation of landforms. Specifically, we discuss the contribution of geomorphological field survey and adapted matrix methodology (in combination with understanding of geology) to identification, study and evaluation of those abiotic nature elements which represent geological and geomorphological heritage. We describe a case study carried out in that part of the protected landscape area "Augsdaugava" which encompasses the Upper Daugava spillway valley. The study programme reported in this paper was realized to perform inventory of landforms and geological features for recognition of objects of particular interest in terms of including them in the list of protected nature monuments. After the field reconnaissance and survey of such objects in situ, the assessment based on several criteria like scientific, aesthetic and paleogeographic value, type, rareness, integrity and representativeness was performed. Obtained data is sufficient to make a well-founded selection of the abiotic nature elements and components of geodiversity, including geological and geomorphological features, e.g. particular landforms as protected nature objects, and to substantiate the need for their conservation. Hence, the output of performed study can be used for enhancing environmental management and conservation of nature diversity and values in this region.
\end{abstract}

Keywords: environmental management, landforms, protected nature objects.

\section{INTRODUCTION}

The appropriate environmental management of territories is a matter of high importance both in terms of planning of socio-economical development and conservation of elements of natural diversity [1], [2]. However, application of the geomorphological approach and assessment of geodiversity as integral part of territorial planning, environmental management and nature conservation is retarded by lack of information as well as by lacking "geoliteracy" of most decision makers and members of local authorities [3].Though, environmentally sustainable management of territories, particularly those which are protected nature areas, requires an integrated understanding of the area to be managed and detailed information about the sites and objects to be protected. In such a context, across Europe, including Latvia, obtaining of data and planning of nature protection measures mainly are focused on elements of biodiversity and biotic nature conservation targets like protected species or habitats [4], [5].

At the same time, the quality and quantity of geological and geomorphological data usually is insufficient to make a well-founded selection of the abiotic nature elements and components of geodiversity, including terrain features, e.g. particular landforms as protected nature objects, and to substantiate the need for their conservation. In turn, the lack of available scientific geomorphological data limits the understanding and insight of local authorities, planners and officers responsible for environmental management in key questions addressed to objects of abiotic nature: what, where and why should they be protected.

One of the solutions to such problems is a geomorphological approach for identification, assessing and mapping of the abiotic nature values, or more specifically, landforms and their complexes with scientific, ecological or landscape importance [6] [10]. 
Landforms are essential part of geodiversity, which, according to Gray [11] can be defined as 'the natural range (diversity) of geological (rocks, minerals, fossils), geomorphological (landform, processes) and soil features. It includes their assemblages, relationships, properties, interpretations and systems. Also this term can be explained as the diversity of geological and geomorphological objects, phenomena and processes in a defined area [12].

Similarly to biodiversity, geodiversity belongs to Earth's nature heritage which must be protected and preserved for next generations [11], [13]. It is also necessary to note, that until the last decade experts do not give so much attention to geodiversity when compared with biodiversity. However, a review of the relevant literature indicates that geodiversity affects much of landscape and ecosystems, or on a larger scale - underpins biodiversity [14] - [16]. It has been recognized, that in areas with higher geological and geomorphological heterogeneity, e.g., areas characterized by explicit relief vertical development or complex patterns of bedrocks and soils, the biodiversity is higher, too [17], [18], and its spatial distribution to a high degree is determined by patterns of landforms [19].

Besides its role in supporting biodiversity, geodiversity simultaneously recognizes both the wider importance as significant information source for the environmental management and conservation, and as background of geoheritage of defined territory. In its turn, geoheritage (like cultural heritage), in terms of socio-economic potential and values for society, is prerequisite for development of local business, e.g. tourism and associated services, allowing diversification of economic activities in the community. Hence, the studies focused on the identification of abiotic nature values and assessment of geodiversity is very important from different viewpoints, including enhancing environmental management and conservation of landforms.

In such a context, the matters mentioned above entirely can be attributed to the Upper Daugava spillway valley. However, until now only very few studies have been focused on these issues [20], [21]. Currently, the legal status of nature monuments is established only to six geological and geomorphological objects which are located in the Upper Daugava spillway valley [22]. However, in this NATURA 2000 site there are many other objects, including geomorphological features, with outstanding scientific or historical meaning, and it is necessary to include them into the list of national or local nature monuments. In other words, the Upper Daugava spillway valley is relatively 'unexplored' in respect of its geodiversity and geoheritage potential. Thus, the geomorphological expertise and detailed geomorphological studies as a basis of the development of the conceptual framework to contribute geomorphic data to the nature conservation policy and management of abiotic nature values in this area is particularly relevant. Without this geomorphic framework, appropriate territorial planning, which has to consider interests of geoconservation, would not be feasible. Hence, geomorphological studies of landforms have straightforward, practical meanings and applications for well-considered and sustainable spatial development.

Therefore, in order to enhance environmental management and conservation of landforms as protected nature objects in the Upper Daugava spillway valley, within the protected landscape area "Augsdaugava", integrated field and desk-based geomorphological study programme presented in this paper were carried out in order to identify and to obtain data about geomorphological objects, in particular, about unique landforms with status of potential nature monuments localised within landscape area "Augšdaugava", as well as to work out necessary measures for their protection.

\section{MATERIALS AND METHODS}

The results presented in this paper are based on data obtained in a course of more than 17 field surveys and desk-based studies conducted in the period 20092014.

Complex geomorphological approach and studies were performed by applying cartographic analysis, field research, GPS and GIS techniques.

First of all, topographic maps at scale 1:10,000 and elevation contour interval of $2 \mathrm{~m}$, as well as thematic geomorphological and geological maps were analyzed to identify and to locate complexes of landforms and pronounced relief features within the Upper Daugava spillway valley. In order to fulfil this task, the standard method [23] of interpreting landforms from maps was applied.

Thereafter field studies of landforms identified by means of cartographic analysis and selected for detailed research were carried out. During the field expeditions, relevant data on their geological, morphological and topographical characteristics were obtained. Such data are essential for additional assessment of geological and geomorphological features in a context of their scientific and scenic/landscape value according to standardized criteria and by application of matrix method.

The matrix method mentioned above, based on scoring procedure proposed by Pralong [24], was adapted and modified considering the type of assessed features as well as the specific character of landscape and local physiogeographic conditions of territory under study. The adapted and modified matrix methodology is based on the evaluation of two groups of criteria: scientific value and scenic/aesthetic value. This methodology can be successfully used for assessment of landforms as geologicalgeomorphological nature monuments in Latvia [25]. 
Concerning the scientific value, the following subcriteria were taken into account: palaeogeographical significance, representativeness, rarity and integrity. Concerning the scenic/aesthetic value, the following sub-criteria were taken into account: perception, average distance, spectacular aspect and colour contrasts. Therefore, visual inspection of the geological and geomorphological objects is essential to an accurate assessment according to criteria by a given matrix method, particularly of their integrity, landscape and aesthetic values. In very details criteria and specific scales of scoring have been described by Pralong [24]. Therefore, considering limitations of the length of the article, authors omit the layout of this methodology. After the assessment in situ both scientific and scenic/aesthetic values were summarised allowing to score studied landforms and to identify geomorphological features with the highest scoring values. Therefore, the application of scoring procedure enables, on the one hand, a comparison of the specific value of different geomorphological objects and, on the other hand, an identification of landforms of the highest scientific, ecological or landscape importance. Moreover, from the criteria scores, well-founded arguments of nomination of landforms to nature monument conservation status may be underlined.

The cross-profiles of landforms were generated by AutoCAD 2008 LT software from the data collected during measurement of slope gradients. These measurements were performed according to conventional geomorphological technique [26] by precise digital clinometer DigiPas DWL-80G (accuracy of measurements $0.1^{\circ}$ ) placed on the rod of $1 \mathrm{~m}$ length, hence reducing the impact of microtopography.

In order to get insight into geochronology of landform formation and thus better to understand their paleogeographic context, the radiocarbon dating was carried out. For these purposes, samples of organic matter were collected within the two types of landforms outstanding in terms or their morphology, i.e. glaciokarst kettles and the U-shaped gully with a local name Aleksandrin rov. The latter on is one of the largest fluvial erosion landforms among those draining headwater catchments adjacent to the Upper Daugava spillway valley. In some of the glaciokarst kettles, small raised bogs have formed. For that reason, it was possible to collect peat undisturbed cores with an Eijkelkamp half-cylindrical chamber peat corer. In such a way, peat samples from depths of $8.20 \mathrm{~m}, 7.35$ $\mathrm{m}$ and 6.35 below the surface were collected. For needs of dating, plant remains were separated from peat samples by wet sieving (deionized water, stainless steel sieve $250 \mu \mathrm{m}$ ). These samples were dated by accelerator mass spectrometry (AMS) ${ }^{14} \mathrm{C}$ method at the Poznan Radiocarbon Laboratory. In its turn wood fragments buried under colluvium in the Aleksandrin rov gully were collected from contact between old gully bed and colluvium cover by split core sampler. The wood fragments AMS ${ }^{14} \mathrm{C}$ dating was accomplished in the Erlangen AMS Radiocarbon Laboratory of the University Erlangen-Nürnberg. All dates were calibrated and converted to calendar years using the online version of the OxCal v.4.2 software [27] and the IntCall3 calibration curve [28].

Additional survey and in situ inspection of landform complexes, which already are included in the list of protected nature monuments [22] also were carried out. It was necessary to verify the conformity of boundaries of areas with protected nature monument status defined by the official regulations with the real situation and location of geomorphological features, which are the protection object of these regulations.

The precise delineation and mapping of all objects was carried out during field surveys by highprecision GPS TRIMBLE Pathfinder ProXRT. Finally, desk-based studies were carried out by application of geographic information systems software and its mapping and visualization tools.

Hence, the integrated geomorphological approach allowed to distinguish the most prominent landforms or their groups with high scientific meaning as elements of geodiversity and geoheritage which should be protected in the Upper Daugava spillway valley.

\section{RESULTS AND DISCUSSION}

The results obtained by application of geomorphological approach and corresponding studies carried out in the Upper Daugava spillway valley indicate, that the area has high geodiversity and geoheritage potential, respectively, high concentration of landforms different in terms of their origin, geological structure and morphology within relatively small area. The realized studies allow to identify the presence of a large variety of geomorphological features like permanent gullies, circular closed depressions of glaciokarst origin, landslide cirques, etc. which are potential protected nature objects.

Analysis of information and applying of matrix method allow to distinguish between other two types of landforms within the study area, which are the most remarkable and valuable in scientific and scenic/aesthetic context. These landforms or their groups are large permanent gullies with U-shaped cross profile and the glaciokarst kettles. During the assessment and scoring procedure both geomorphological features obtain the highest scoring values, i.e. 20 and 21 points of scientific value, 26 and 28 points of scenic/aesthetic value. Therefore detailed geomorphological data, discussed hereinafter, were obtained on permanent gullies and the glaciokarst kettles.

In the group of permanent gullies, there are more than 350 erosion landforms dissecting slopes of the 
Uppers Daugava spillway along the 50-km-long river stretch from Kraslava town down to Krauja village. However, assessment of these relief elements by matrix method on purpose to identify potential protected geological-geomorphological nature monuments, allowed to highlight one object - the gully Aleksandrin rov. This geomorphic and landscape feature representing landforms formed during longterm water erosion processes, is located on the right slope of the spillway valley near Slutiski village, Daugavpils district. The gully Aleksandrin rov is Ushaped, flat-bottomed permanent gully with very high aesthetic and landscape value (Fig. 1) and belongs to the largest fluvial erosion landforms among those draining headwater catchments.

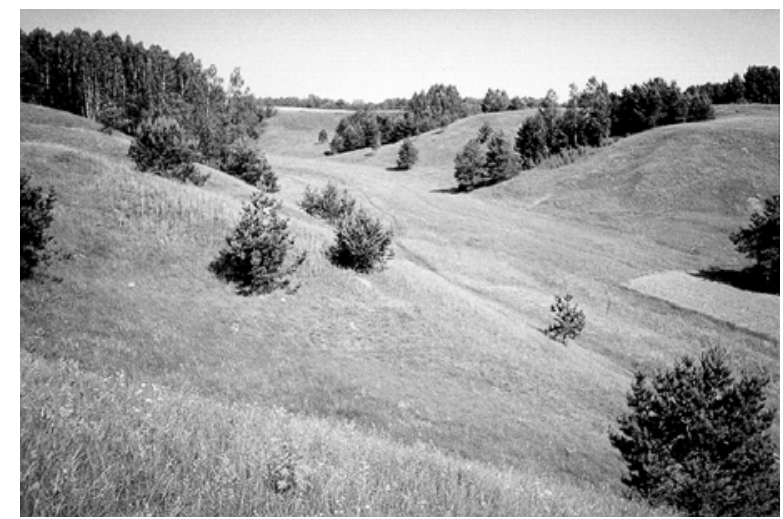

Fig. 1. Old flat-bottomed dry gully Aleksandrin rov with typical Ushaped cross-profile. Gully is located in the Upper Daugava

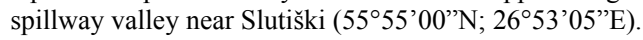

Such geomorphological features which have a local name vecgravas look similar to small dry grassed valleys and equals to East European balkas. There is no evidence of current erosion processes in the Aleksandrin rov due to the dense cover of grass vegetation. This landform is characterised by impressive morphology, i.e. its max. depth is $18 \mathrm{~m}$, max. width is $115 \mathrm{~m}$, length exceeds $2.0 \mathrm{~km}$, and gully has a typical U-shaped or trapezoidal cross-sectional profile (Fig. 2).

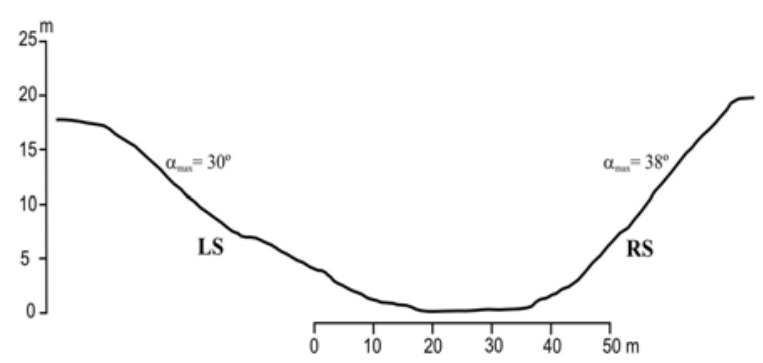

Fig. 2. Cross profile of the gully Aleksandrin rov. $\mathbf{L S}=$ left sidewall of gully; RS = right sidewall of gully; $\boldsymbol{\alpha}_{\mathbf{m a x}}=$ maximal slope gradient of measured cross-profile.
The ${ }^{14} \mathrm{C}$ dates of wood buried under colluvium in this gully reveal age $1990 \pm 75 \mathrm{BP}$, ca. 195 cal $\mathrm{BC}-$ 178 cal AD (Erl-10456), hence indicating that the infilling and stabilization of this old gully in the Upper Daugava spillway valley took place before the beginning of intensive agricultural activities in this region. Considering the dimensions of this gully and results of paleohydrological modelling [29], the Aleksandrin rov refers to the Pleistocene or lateglacial old gullies. The formation of such late-glacial old gullies was initiated in periglacial conditions by intensive streams resulting from melting stagnant glacial ice blocks during the retreat of ice sheet from SE part of Latvia. Considering its scientific, paleogeographic and landscape values, this landform should be included in the list of protected geologicalgeomorphological nature monuments in Latvia.

Among other landforms, the glaciokarst kettles are outstanding in terms of their morphology, paleogeographic and scientific values. These kettles are presented as semi-circular, slightly elongated funnel-like closed depressions, which form groups in the Upper Daugava spillway valley. Within groups, the longitudinal axes of these negative landforms have similar orientation. GIS-based geospatial analysis elucidates that the groups of glaciokarst kettles in planar view are distributed in a form of slightly undulated band. (Fig. 3). The local name of glaciokarst kettles within the Upper Daugava spillway valley is 'valna dubes (devil's holes)'. Such morphologically similar landforms, characterized by the steep radial hillslopes which encircle isometric or elongated funnel-like depression, have been reported in the literature as landscape features of north-eastern Europe within territories formerly covered by the Late Weischelian glaciation [30].

Dominant explanation reported in the literature on origin and morphology of these negative landforms associates their formation with glaciokarst processes [31].

Hence, glaciokarst kettles have been formed by melting out from dead ice blocks, which were buried under glaciofluvial sediments deposited by ice meltwater streams in the Late Pleistocene.

In total, there are 58 glaciokarst kettles within the stretch of spillway valley stretch from Kraslava town down to Krauja village. The results of the field studies show that those geomorphological objects are relatively large, e.g. their dimensions may reach hundreds of meters. These landforms are located on a surface of different terraces of the spillway valley, and at varying hypsometric levels. Their depth ranges from several $\mathrm{m}$ to maximum $36 \mathrm{~m}$, values of coefficient of roundness lies between 1.01 and 2.34, and ratio of $\mathrm{a} / \mathrm{b}$-axis is from 5.04 to 1.09 . The most impressive and deepest closed depressions are located within the Tartaka meander of the spillway valley (Fig. 4). 


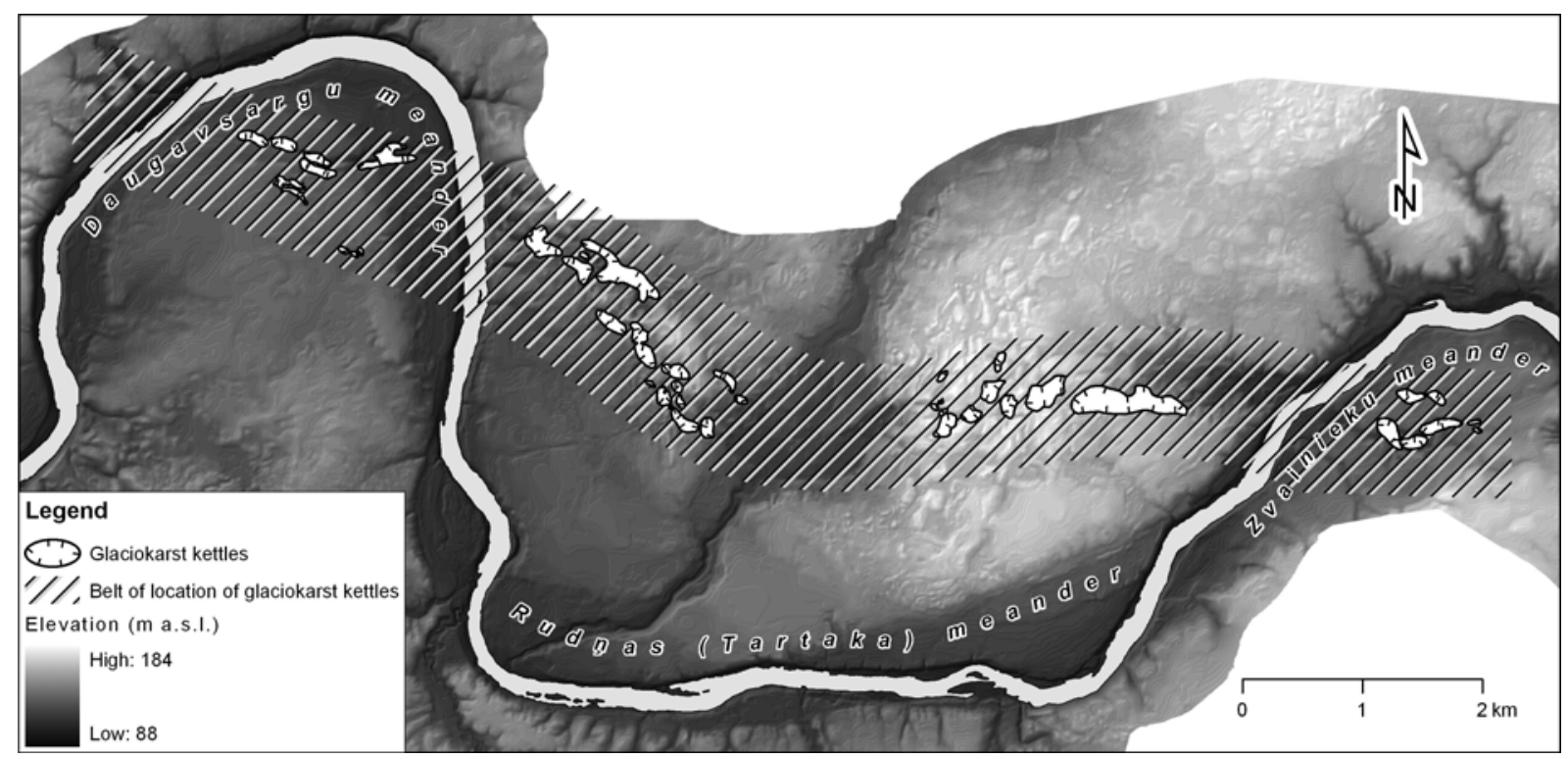

Fig. 3. Geographical distribution of glaciokarst kettles within the middle part of the Upper Daugava spillway valley, showing relief by a shaded DEM in the background.

In several such depressions, small raised bogs have been formed with a thickness of peat layer up to 8.75 $\mathrm{m}$. The fragments of plant remains collected from the peat samples from one of glaciokarst kettle at depths of $8.20 \mathrm{~m}, 7.35 \mathrm{~m}$ and 6.35 below the surface yielded AMS ${ }^{14} \mathrm{C}$ dates of $10,704 \pm 50 \mathrm{cal}$ yr BP (Poz-60631), $8510 \pm 40 \mathrm{cal}$ yr BP (Poz-60633) and $7935 \pm 35 \mathrm{cal} \mathrm{yr}$ BP (Poz-60634), respectively. These results indicate that the formation of glaciokarst kettles can be referred to the end of the Late Pleistocene and beginning of the Early Holocene. However, additional studies like optically stimulated luminescence dating of sand which composes the slopes of glaciokarst kettles as well as using of ground penetrating radar for better understanding of geological structure of these landforms should be performed.

Moreover, these landforms, which formed during the subsequent development of the spillway valley, also provide relevant paleogeographic information about the processes of their formation and the time when it occurred.

Consequently, considering their scientific and landscape significance, part of glaciokarst kettles should be registered in the list of protected nature objects of national importance.
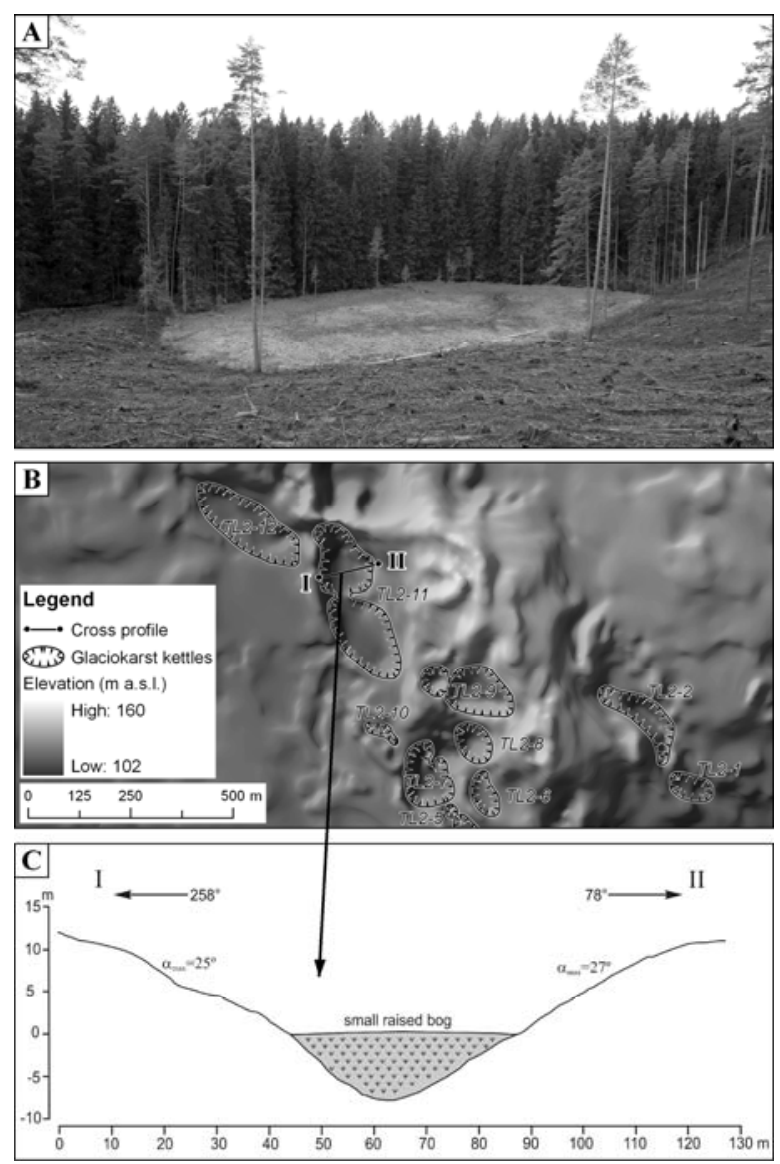

Fig. 4. (A) Photo of the glaciokarst kettle TL2-11 with small raised bog within it, where peat core were obtained for AMS $14 \mathrm{C}$ dating.

(B) Digital elevation model of cluster of glaciokarst kettles TL located in the eastern part of the Tartaka meander. (C) Cross profile of kettle TL2-11. 
At last it is necessary to note, that additional survey and in situ inspection of landform complexes "Sandarisku karengravas" and "Sprogu gravas", which both already are included in the list of protected nature monuments, also were performed. Results of the survey indicate that boundaries of these protected nature monuments defined by the official regulations [22] and depicted in corresponding maps do not conform to the real situation. Thus, $43 \%$ of the area, where hanging gullies with very high paleogeographic and scientific value is located, are outside the recent location of the nature monument "Sandarisku karengravas". Similarly, $17 \%$ of the area of landslidegully complexes in the nature monument "Sprogu gravas" is located outside the borders of protected territory. This fact highlights the obvious need of implementation of changes in existing regulations and precise delineation of borders of geologicalgeomorphological nature monuments in terms of enhancing their environmental management and conservation within the Upper Daugava spillway valley.

\section{CONCLUSIONS}

The results of the given research permit to draw several important conclusions about the options and reliability of the application of geomorphological approach for enhancing environmental management and conservation of protected nature objects in the Upper Daugava spillway valley.

The integrated studies by application of geomorphological field survey, GIS techniques and adapted matrix methodology have advantages in terms of identification, assessing and mapping of the abiotic nature values, and, in particular, landforms as well as their complexes with scientific, ecological or landscape importance. The geomorphological approach allows to come up with answers to key questions addressed to objects of abiotic nature: what, where and why they should be protected. Hence, the communication of scientists and experts in nature protection with local authorities and decision makers can be substantially improved in respect of matters of territorial planning at municipal and even at the national level.

The results of studies allow to distinguish among other landforms the gully Aleksandrin rov and glaciokarst kettles as the most valuable and important part of geodiversity and geological heritage of the Upper Daugava spillway valley. These landforms should be included in the list of protected geologicalgeomorphological nature monuments in Latvia, as well as regulations aimed to provide their conservation and protection should be elaborated. In order to reduce negative socioeconomic effects associated with limitations due to protection and conservation measures, it is necessary to realize further studies focused on development of nature tourism based on sustainable usage of potential of nature values including landforms, hence enabling the development of local business. Thus, the geomorphological expertise and detailed geomorphological studies of landforms have essential meanings and applications for spatial development planning without conflicting interests of geoconservation in the Upper Daugava spillway valley.

Last but not least, the obvious need for additional research in order to find other geomorphological and geological objects, which are an important part of geodiversity and nature heritage of this region.

\section{ACKNOWLEDGMENTS}

The authors are grateful to prof. Aija Melluma for her suggestion to perform these researches, as well as to M. Petrovs, A. Puckins, V. Semjonovs, A. Treijs, A. Skrupskis, J. Varsbergs and D. Kursits for their assistance in the fieldwork.

\section{REFERENCES}

[1] C. D. Prosser, D. R. Bridgland, E. J. Brown and J. G. Larwood, "Geoconservation for science and society: challenges and opportunities," Proceedings of the Geologists' Association, vol. 122 (3), pp. 337-342, Jun. 2011.

[2] C. Fassoulas, D. Mouriki, P. Dimitriou-Nikolakis and G. Iliopoulos, "Quantitative assessment of geotopes as an effective tool for geoheritage management," Geoheritage, vol. 4 (3), pp. 177-193, Sept. 2012.

[3] I.S. Stewart and T. Neild, "Earth stories: context and narrative in the communication of popular geosciences," Proceedings of the Geologists' Association, vol. 124, pp. 699-712, June 2013.

[4] M. Gray, J. E. Gordon and E. J. Brown, "Geodiversity and the ecosystem approach: the contribution of geoscience in delivering integrated environmental management," Proceedings of the Geologists' Association, vol. 124 (4), pp. 659-673, Jun. 2013.

[5] L. Erikstad, "Geoheritage and geodiversity management - the questions for tomorrow," Proceedings of the Geologists' Association, vol. 124 (4), pp. 713-719, Jun. 2013.

[6] G. Bocco, A.Velázquez, C. Siebe, "Using geomorphologic mapping to strengthen natural resource management in developing countries. The case of rural indigenous communities in Michoacan, Mexico," CATENA, vol. 60 (3), pp. 239-253, Mar. 2005

[7] E. Reynard and M. Panizza, "Geomorphosites: definition, assessment and mapping," Géomorphologie: relief, processus, environnement, vol. 3, pp. 177-180, Mar. 2005.

[8] A. Carton, P. Coratza and M. Marchetti, "Guidelines for geomorphological sites mapping: examples from Italy," Géomorphologie : relief, processus, environnement, vol. 3, pp. 209-218, Mar. 2005.

[9] P. Coratza and G. Regolini-Bissig, "Methods for Mapping Geomorphosites," in Geomorphosites, E.Reynard, , P.Coratza, G.Regolini-Bissig, Eds., Pfeil, Munchen, pp. 89-103. 2009.

[10] I. Fuertes-Gutiérrez, E. Fernández-Martínez, "Mapping Geosites for Geoheritage Management: A Methodological Proposal for the Regional Park of Picos de Europa (León, Spain)," Environmental Management, vol. 50 (5), pp. 789806, Nov. 2012.

[11] M. Gray, Geodiversity - Valuing and Conserving Abiotic Nature. Chichester: John Wiley \& Sons, Ltd, 2004, 434 pp.

[12] C.E. Johansson and M. Alpassi, "Geodiversitet i Nordisk Naturvård," vol. 8., Nordic Council of Ministers, Nord, pp. 1149, 2000. 
[13] C. Sharples, "A Methodology for the Identification of Significant Landforms and Geological Sites for Geoconservation Purposes," Report to Forestry Commission, Hobart, Tasmania, 31 pp. 1993.

[14] J.E. Gordon and H.F. Barron, "Scotland's geodiversity: development of the basis for a national framework," Scottish Natural Heritage Commissioned Report No. 417, 2011.

[15] J. Bradbury, "A keyed classification of natural geodiversity for land management and nature conservation purposes," Proceedings of the Geologists' Association, vol. 125 (3), pp. 329-349, Jul. 2014.

[16] T.J. Mathews, "Integrating geoconservation and biodiversity conservation: theoretical foundations and conservation recommendations in a European Union context," Geoheritage, vol. 6 (1), pp. 57-70, Mar. 2014.

[17] C. Müller, G. Berger, M. Glemnitz, "Quantifying geomorphological heterogeneity to assess species diversity of set-aside arable land," Agriculture, Ecosystems \& Environment, vol. 104 (3), pp. 587-594, Dec. 2004.

[18] E. Reynard, G. Fontana, L. Kozlik, C. Scapozza, "A method for assessing "scientific" and "additional values" of Geomorphosites," Geographica Helvetica, vol. 62 (3), pp. 148-158, 2007.

[19] J. Soms, "Biodiversity as a result of diversification of the environment: the significance of erosion processes in ecosystems changes - case study in Nature Park „Daugavas loki", in Book of abstracts of the 3rd International Conference Research and Conservation of Biological Diversity in Baltic Region, Daugavpils, Latvia, 20 - 22 April, 2005, p.114.

[20] D. Kursīts, “Nature monuments within Nature Park „Daugavas loki" in context of nature tourism and nature protection arrangements (Dabas pieminekḷi dabas parkā „Daugavas loki” dabas tūrisma un dabas aizsardzības pasākumu kontekstā)," M.S. thesis, Daugavpils, Daugavpils University, 74 pp., (in Latvian), 2009.

[21] E. Muižniece, "Studies of relief features in the nature park "Daugavas loki" for including them in the list of protected nature monuments (Dabas parka „Daugavas loki” savdabīgo reljefa veidojumu izpēte to iekḷaušanai aizsargājamo dabas objektu sarakstā)," M.S. thesis, Daugavpils, Daugavpils University, 814 pp., (in Latvian), 2013.

[22] Nature Conservation Agency, "Nature monuments of Latvia". Available: http://www.daba.gov.lv/public/eng/protected_areas/ [Accessed: Janv. 12, 2015].

[23] D.J. Easterbrook and D.J. Kovanen, Interpretation of Landforms from Topographic Maps and Air Photographs. New Jersy: Prentice Hall, 194 pp., 1999.

[24] J-P. Pralong, "A method for assessing tourist potential and use of geomorphological sites," Géomorphologie: relief, processus, environnement, vol. 3, pp. 189-196, Mar. 2005.

[25] L. Bolšija and J.Soms, "Landforms as geologicalgeomorphological nature monuments in the National park Rāzna (Reljefa formas kā ǵeoloǵiski-ǵeomorfoloǵiskie dabas pieminekḷi Rāznas nacionālajā parkā”. In proceedings of the 15th International Scientific Practical conference of students "Human. Environemnt. Technology", Rēzekne, 27 April 2011, Rēzekne Highschool press, pp. 22. - 33, (in Latvian with summary in English) 2011.

[26] A. Young, D. Brunsden, J.B. Thornes, "Slope profile survey," British Geomorphological Research Group Bulletin No. 11, Norwich: Geo Abstracts, 52 pp., 1974.

[27] C. Bronk Ramsey, S. Lee, "Recent and planned developments of the program OxCal," Radiocarbon, vol. 55 (2-3), pp. 720730, Jul. 2013

[28] P.J. Reimer, E. Bard, A. Bayliss, J. Warren Beck, P.G. Blackwell, C. Bronk Ramsey, C.E. Buck, H. Cheng, R.L. Edwards, M. Friedrich, P.M. Grootes, T.P. Guilderson, H. Haflidason, I. Hajdas, C. Hatte, T.J. Heaton, D.L. Hoffmann, A.G. Hogg, K.A. Hughen, K.F. Kaiser, B. Kromer, S.W. Manning, M. Niu, R.W. Reimer, D.A. Richards, E.M. Scott, J.R. Southon, R.A. Staff, C.S.M.Turney and J. van der Plicht, "Intcal13 and Marine13 radiocarbon age calibration curves 050,000 years cal BP," Radiocarbon, vol. 55 (4), pp. 1869 1887 , Oct. 2013

[29] J. Soms, "Development and Morphology of Gullies in the River Daugava Valley, South-Eastern Latvia," Landform Analysis, vol. 17, pp. 179-188, Febr. 2011.

[30] M. Bennet and N. Glasser, Glacial Geology: Ice Sheets and Landforms. 2nd edit. John Wiley \& Sons, 400 pp., 1997.

[31] T. Kalettka and C. Rudat, "Hydrogeomorphic types of glacially created kettle holes in North-East Germany," Limnologica - Ecology and Management of Inland Waters, vol. 36 (1), pp. 54-64, 2006. 